\title{
Efficiency Analysis of the Photovoltaic Systems for Carbon Footprint Reduction (Case Study: University of East London)
}

\author{
Hossein Jahankhani ${ }^{1}$, Amin Hosseinian-Far ${ }^{1, *}$ \\ ${ }^{1}$ University of East London, ACE, 4-6 University Way, London E16 2RD UK
}

E-Mails: H.Jahankhani@uel.ac.uk, Amin@uel.ac.uk

* Author to whom correspondence should be addressed; Tel.: +447720377693 Fax: +442082232963

Received: / Accepted: / Published:

\begin{abstract}
The current energy crisis has shifted human efforts towards looking for and using renewable energy sources. One of the well-known of these, is the solar energy. The two well-known harvesting systems are PV and solar thermals. This paper tries to reflect the Photovoltaic systems in general in first instant. Furthermore it considers the efficiency analysis of the PVs by means of RETScreen 4 software. The case study chosen for this paper is University of East London located in London, England. The analysis is based on the RETScreen library and NASA related location statistics.
\end{abstract}

Keywords: Climate Change Levy, Feed-in-tariff, RETScreen, Emission Analysis, Energy Model

\section{Introduction}

Energy is crucial to all aspect of human life. In many of countries, the energy is generated in a way which is not sustainable and consequently causes greenhouse gases production. The energy which is engendered by burning the fossil fuels such as coal, and oil is the cause for environmental deterioration and climate change. In addition the fossil fuels are the limited sources of energy and will be ended in the near future. Based on the International Energy Agency (IEA) in Paris, the usage of energy will be 
raised about $60 \%$ and it would be risky to trust this amount of energy requirement from the fossil sources. (Toklu et al May 2010)

The latest world energy council study demonstrates that there will be no revolution in existing energy production, and also by 2020 the request of energy would be increased roughly $50 \%-80 \%$ in compared to 1990 baseline. This expanding demand and the emission of CO2, CO, SO2 which are causing the global warming have become the center of attention in order to avoid un-sustainability. On the other hand growing population of the world necessitates more energy. Figure 1. illustrates the industrialized economy and raising order of energy which is about the $75 \%$ of overall energy source in the world. Today the Result of evaluation of energy consumption is 22,109 $\mathrm{kW} \mathrm{h}$ per year. (Omer, 14 August 2009)

Figure 1: Annual and estimated world populations and energy demands (Omer, 14 August 2009)

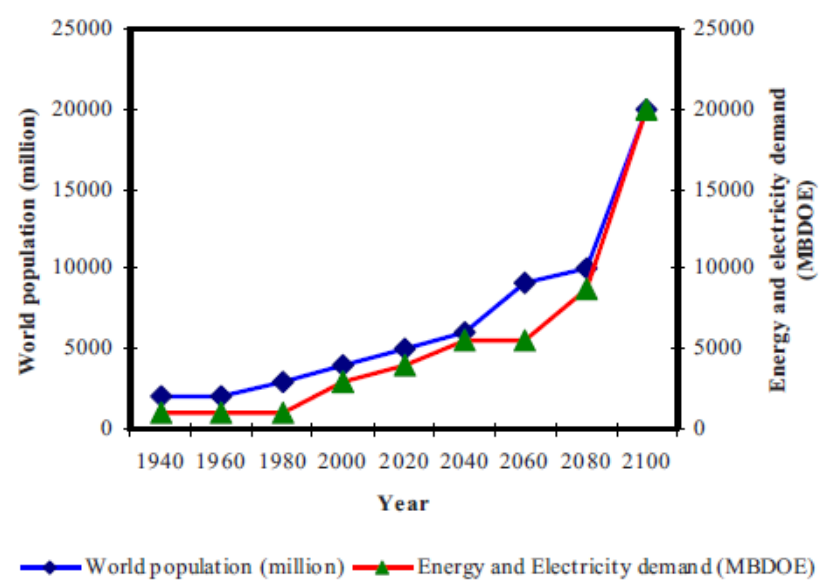

Multi-criteria analysis shows that the energy produced by the fuel such as oil and coal is threatening the environment to fall in a descent way. Renewable energy and nuclear energy is the greatest solution to overcome the environmental deterioration and could supply the world's energy in next century. (Mirasgedis, 1997)

There are many debates about the nuclear energy and consequent probable environmental threats, but about the renewables, there is some kind of consensus by many experts and in general all the states. Environmental bearing and recourse degradation are two major problem of fossil fuel. The energy of reserved fossil fuel is decreasing everyday by the increased demand. Figure 2. illustrates the reserve fossil fuel in America, Asia, Europe, and Asia Pacific.

Figure 2: The reserve fossil fuel in America, Asia, Europe, and Asia Pacific. (Mirasgedis, 1997)

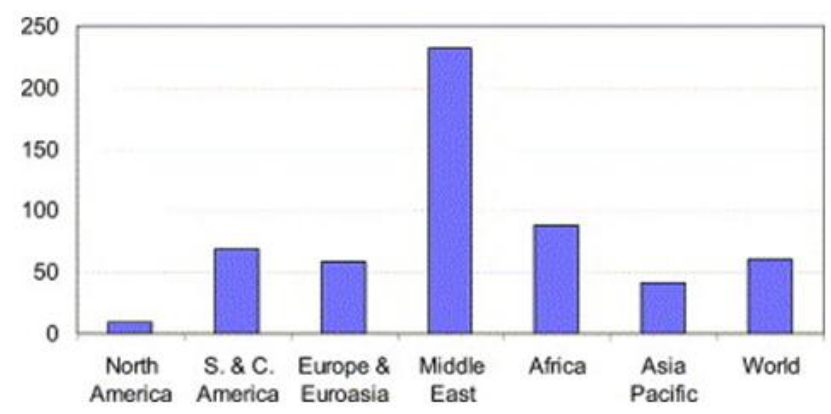

Upgrading and emphasizing the renewable energy market will be a factor for ecosystem endurance by decreasing the emission in general. Almost all research works done previously show that the 
electricity produced by renewable energy is carbon free and its process does not generate the greenhouse gases. Using the renewable energy for generating the electricity is considering both the environmental and economic point of view. (Muneer, 2005)

Energy security and climate change have led to a large talk about. Furthermore, the viewpoint of irreversible climate change and energy security has caused major investments; and achievements of regulatory tools like trade and carbon cap (e.g. Emissions Trade Scheme in Europe). Having had the first phase of development of alternative energies in the 1970's as a result of the Arab oil embargo and the subsequent price hike, the second phase has continued in the first decade of the 21 st century. With the Copenhagen summit quickly approaching, policymaker at a crossroads and the incidence of the climate change emphasizes the political and social pressures facing policy makers and the relevant scientists (Stringer, 2009).

\section{Types of renewable energies}

Renewable energy potential is substantial. The computed result of using solar, hydropower and geothermal as well as the new exercising of biomass possibly shows that they can produce sufficient energy for supplying the population of the world more than a few times over. As the practical point there is only a small number of technologies for utilizing renewable energies have verified to be useful, whilst the economic viability point is also bounded to limited certified counties in the world. Frequently, markets are robustly altered by grant in keep of fossil fuel, put down renewable energies at a weakness. (Boyle, 1998)

\subsection{Solar energy}

Solar power is the category of renewable energy that is being regarded with grand potential of supply of $0.05 \%$ of total energy demands. The earth obtains $4.3 \times 1020$ joules of sun ray in an hour which could supply the request of the human of roughly $4.1 \times 1020$ joules in a year (Biello, 2008). Photovoltaic solar cells have had a schism in recent years, and that is due to the introduction of new technologies such as 'Thin Film' panels. Hosseinian-Far et al 2010).

Solar power is in two categories: solar thermal which can be utilized to produce the heat, PV (photovoltaic) which is used to produce the electricity straightly from sun. In solar thermal the water is moving in tubes and is heated up via the sun that is used to make the electricity and the mirror is applied for sending the sun rays to warming containers (Bilena et al 2008).

The PV (photovoltaic) is the energy technology for generating electricity directly from the sun. For Photovoltaic cells silicon is retrieved from sand. Every PV cell is composed of two sections: negatively charged and positively charged. The photovoltaic cell is quite strong, has cheap maintenance and is very valuable technology for the countries with affluent sunshine. (Martinot, 2006)

Figure 3. illustrates $60 \%$ growth of PV between the 2000 and 2004: 
Figure 3: PV growth between the 2000 and 2004. (Martinot, 2006)

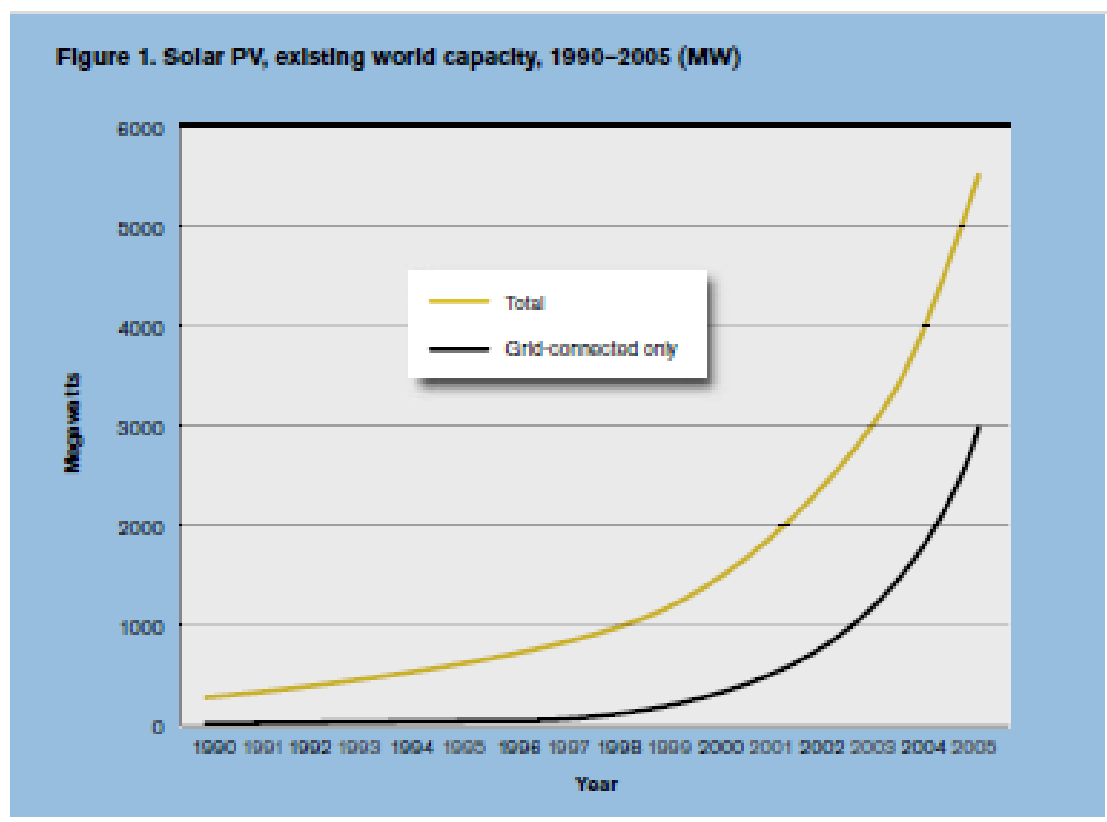

The solar output would be more valuable in regions with high-quality sunshine. Contrasting the output and cost of solar energy with coal and gas recourses represents that the solar is unattractive on $\$ / \mathrm{kWh}$ criteria. The capacity factor of coal, gas and nuclear is greater than $75 \%$ even though for the solar is usually at most $25 \%$ (Boyle, 2009). This small amount of capacity factor and the low level of efficiency for the solar are the reasons intended for many developed countries to promote the usage of renewable energy such as solar. "Feed-in tariff "are paid as result of every part of electricity a household generates. UK set up the feed-in tariff in April 2010 that put the 36.5p for installation of each unit and additional 5p for every unit being granted to National Grid (Southern Electric, 2009). In the UK, the climate change levy and the other tools such as Climate Change Agreement is introduced for corporations in order to decrease levy to $80 \%$ by agreement of reducing the carbon. Climate Change Levy leads to 2.9\% reduction of whole energy demand in 2010 (Cambridge Econometrics, 2005).By the evaluation of economic issue of solar technology and usual fuel resources seems that the solar is supposed to be more cost-effective and reliable. Major examinations and research works, current commercial condition, declination prices confirm that solar photovoltaic (PV) is among the greatest and easiest carbon free energy producer systems within domestic scale. Low cost maintenance, 25 years of secure power, distant monitoring alternative and considerable energy production could be measured as some benefits of solar photovoltaic.

Photovoltaic technology is considered as a system which provides electricity without any pollution and can be set up in commercial and residential areas; however it releases the greenhouse gas. The growth of Photovoltaic system has been 1.5 GW over 2005 especially in European countries such as Germany.

Generally there are three type of PV cell technology: amorphous, mono-crystalline, and polycrystalline which the GHG emissions are varying in each form. Based on Life Cycle Assessment (LCA) the energy consumption for constructing the photovoltaic power plants is between 13,000 to $21,000 \mathrm{kWh} / \mathrm{kWp}$. Amorphous system present the $3.360 \mathrm{~kg}-\mathrm{CO} 2 / \mathrm{kWp} \mathrm{CO} 22$ emission and the energy pay-back time was about 2.5 to 3 years for putting in rooftop and 3 to 4 years for multi-megawatt ground installation technology. This silicon is non-crystalline (Sherwani et al 2010). Brazil has the 
most annual total solar radiation rate in contrast with all European Union states like Spain and Germany but in EU RE is more considerable. In a PV panel the translation of energy to electricity is happening within photovoltaic cells.

Energy storage scheme and load management are two factors which can be considered in order to decrease the price of photovoltaic installation. The technology of energy storage deal with the broad ranges of energy system requests. Flow batteries, Sodium-Sulfur batteries (NaS), super capacitors, Nickel-Cadmium (Ni-Cd), Lithium-Ion (Li-ion) are some of the well-known storage technologies.

\section{2,2 How does the PV work?}

Today, Photovoltaic is the most common application which is measure as the sustainable energy producer. In photovoltaic cells there is a device which is called semiconductor. It translates sun rays into DC current. The standard PV solar silicon is made of two layers: phosphorus-doped (N-type) and boron-doped (P-type). The N-type silicon is located in top of the P-type silicon. The connection of these two silicones is called P-N junction and actually the electricity is created in this area. The sunlight radiation on PV cell is causing momentum granted and light motivated electrons to generate electricity. The current output of PV depends on the size and strength degree of sun rays shining. Solar cells are located in the secure place which called photovoltaic modules. Furthermore photovoltaic panel consists of number of photovoltaic modules. All these PV panels and modules are put on integrate power-producing area called an array. Photovoltaic topology is categorized in two fields: standalone system and grid-connected. In Standalone photovoltaic topology there is no need of utility grid and it is designed to supply the DC and AC electrical loads. In this type the energy is generated by PV array or utility power as a supplementary source which is called PV-hybrid system. Standalone photovoltaic operates with batteries (Florida Solar Energy, May1999).Grid-connected without battery is only working with the utility grid. In grid-connected type there is the base component which is named converter and it converts the DC current of PV array to the AC current. Another important component is BOS that is the wiring system used to incorporate the solar modules in a way to meet the required installation structure. This structure consists of current defense, groundfault defense and cut of the DC and AC of inverter surfaces. Meter is the device used to evaluate the system performance.

Figure 4: Grid-interactive PV system w/o battery. (Gray-Davis, JUNE 2001)

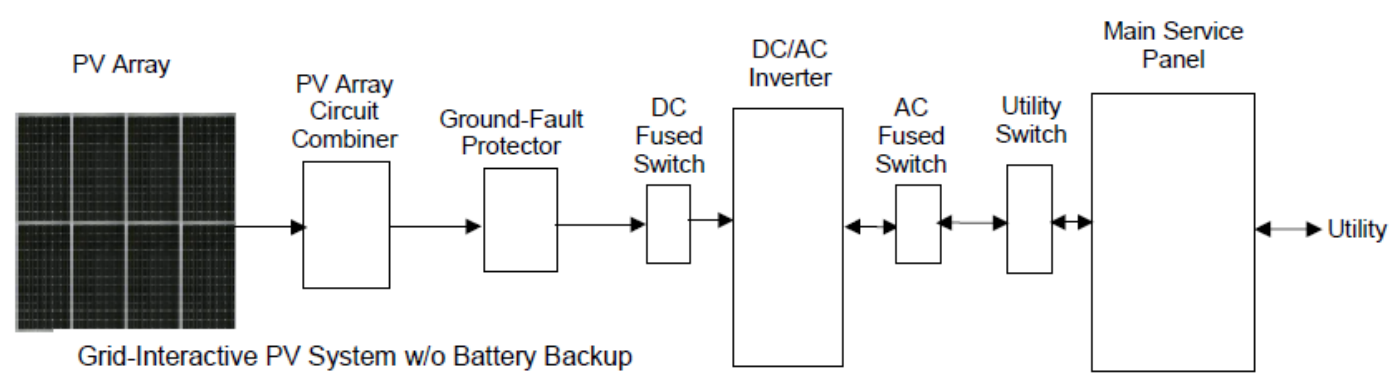

\section{Calculated the energy model in the case of UEL}


The energy model has calculated overall annual output of around 32MWh, with a breakeven point (assuming Feed in Tariffs at $36.5 \mathrm{p}$ and savings of $7 \mathrm{p} / \mathrm{kWh}$ ) for 13 years after a $30 \%$ capital costs grant with debt covering the remainder at $10 \%$ over a 10 ten year period. The annual return is $2.5 \%$ based on total capital cost, or $3.2 \%$ based on whole minus the grant, through the original project plan to a cumulative cash flow of $£ 150,000$ by the 25 th year. Although 13 years is a period much longer than most companies would consider reasonable to wait for Return on Investment (RoI). Wholesale electricity prices in the UK will serve as a reference with which to compare the university's solar system. Electricity prices have averaged 0.07-0.09 £/kWh (Department of Energy \& Climate Change, 2009) for industrial scale users in the past 2 years, and University of East London is assumed to pay similar rates. In order to assess the installed array's power cost on a per kWh basis, several parameters need to be defined. These values are estimated and detailed in the table below:

Table 1: PV Variable values

\begin{tabular}{|ll|}
\hline Parameter & Value \\
\hline Solar Tracking Mode & Fixed \\
\hline Project Life & 25 years \\
\hline Efficiency & $12 \%$ \\
\hline Misc Losses & $1.0 \%$ \\
\hline Feed in Tariff & $0.365 £ / \mathrm{kWh}$ \\
\hline Inverter Efficiency & $90 \%$ \\
\hline Capacity Factor & $14.6 \%$ \\
\hline Total Electricity Exported & 0 \\
\hline Annual O\&M Costs & $500 £$ \\
\hline Debt Amount & $113,957 £$ \\
\hline Debt Term & 10 years \\
\hline Debt Interest rate & $10 \%$ \\
\hline
\end{tabular}

\section{Emission analysis in case of UEL}

The greenhouse gas analysis currently yields annual savings of 18.2 tons of CO2 based on the UK's average CO2 emissions of $465 \mathrm{~kg} / \mathrm{MWh}$ with $1 \%$ accounting for Distribution losses.

Figure 5: RETScreen Emission Analysis

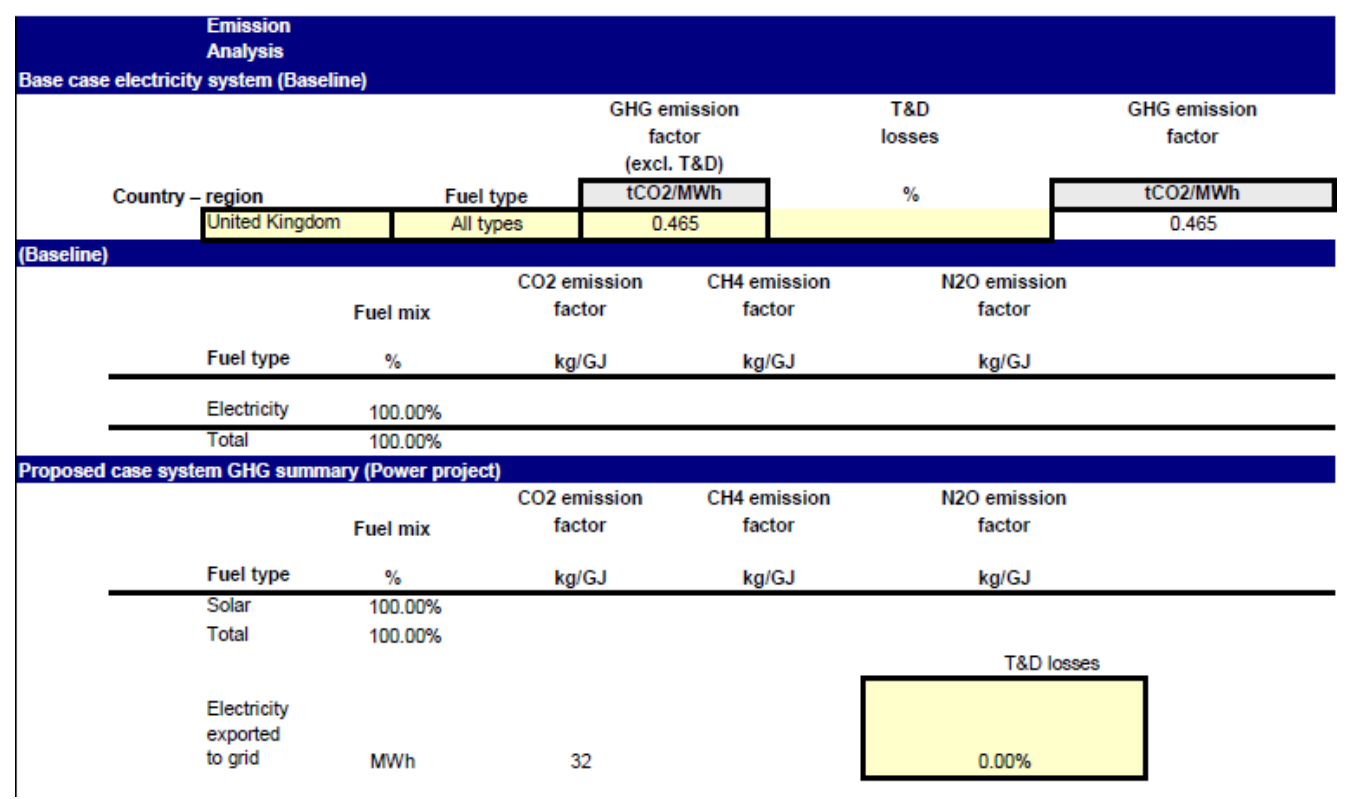




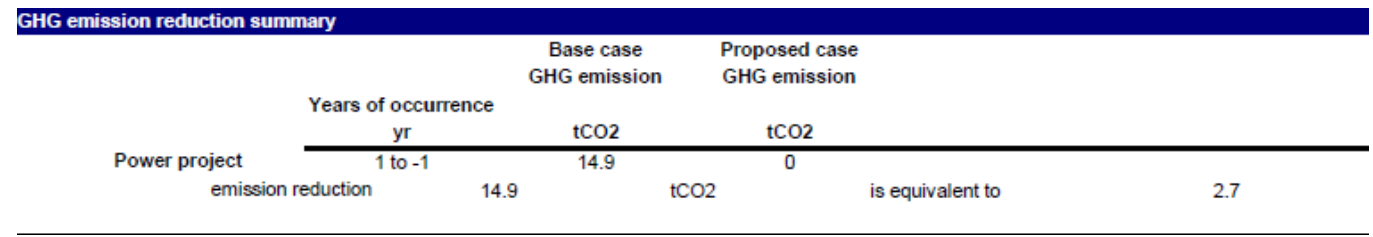

Financial analysis of PV considers a significant difficulty dealing with supplier and customer. The major assets cost could effect on the system economical viability principally if debt is a requirement. In this analysis, all financing has been supposed to be totally by debt and grant. It is presumed that the grant have been offered as the section of Low Carbon Buildings Program that assign funds for to familial and commercial users who desire to leave renewable energy setting up like small PV panels and wind turbines on their possessions. The grant is estimated to fund $30 \%$ of the whole assets cost, whereas debt cover up the remains in excess of a ten year episode. For decrees the risk of project, the interest rate is estimated about $10 \%$. The rate of debt require to be paid is about 18500 rate for each year. The sum deficit in this stage achieves a greatest of slightly in excess of $£ 52,000$ in the tenth year, creation a fund of the same size essential to cover the losses on the debt a necessity over the whole debt period. All costs will have been computed for, and the cash flow turns into optimistic, behind the tenth year. In the 13th year, the breakeven point is achieved, and next to the 25th and ending of the project, there is a cumulative optimistic cash flow of around $£ 150,000$ over the entire 25 year phase, based on whole initial costs of roughly $£ 163,000$. The cash flow is estimated to be completely from savings feed in Tariffs, by means of the total of the electricity return to the university.

$\mathrm{Via}$ the values outlined in energy model table, the energy model yield an annual output of 32MWh and a capacity factor of approximately $14 \%$ based on London's historic weather data. The rooftop array's output for the operational period of July-November has been approximately 10.7MW. The NASA climate data specifies that the array would have received $44.44 \%$ of its overall annual radiation in this time. Estimating a linear connection among output and daily solar radiation, an output rate of $11.78 \mathrm{MWh}$ is derived. The difference between the theoretical and actual output may be clarified by the variability of atmospheric cause like cloud movements, as well as the non-linear link between solar radiation and output .By alteration different parameters, agreed that the panels are stationary, the most major issue persuading power throughput was determined to be the panels' efficiency. A brief explanation of the system's parameters will be given. The output of a module is reliant in fraction on the angle at which the solar radiation coincides with the panel (i.e. at an optimum angle, there's a higher watt per area). The tracker tracks the sun's position in the sky and adjusts the panel's angle to an optimum value. In our RETScreen calculations, installing a single or two axis tracker can result in up to a $24 \%$ increase in annual output. The project life is necessary in that the cost of solar PV is mostly due to its high capital costs; the longer that a project runs, the greater the return on the original investment. Cell efficiency in nature contacts the whole output per cell part, with the efficiency of the inverter impacting on how much of that total output is fed in as AC electricity. Operations \& Maintenance (O\&M) costs can be considerable if the whole value of the output is low, and finally influenced the Return on Investment (RoI) rate. The total amount of debt is one of the most significant factors affecting the ROI. The discount rate is an additional significant tool in evaluating the project's viability. The discount rate can be dependent on the project's capital costs, inherent risk, and general market conditions (i.e. return rate compared to other similar investments). The discount rate is at 
present suggested at 3.5\% by the HM Treasury Green Book (HM Treasury, 2009), while upper rates were chosen to consider advanced loan interest rates.

Figure 6: Economy Analysis for the Case Study

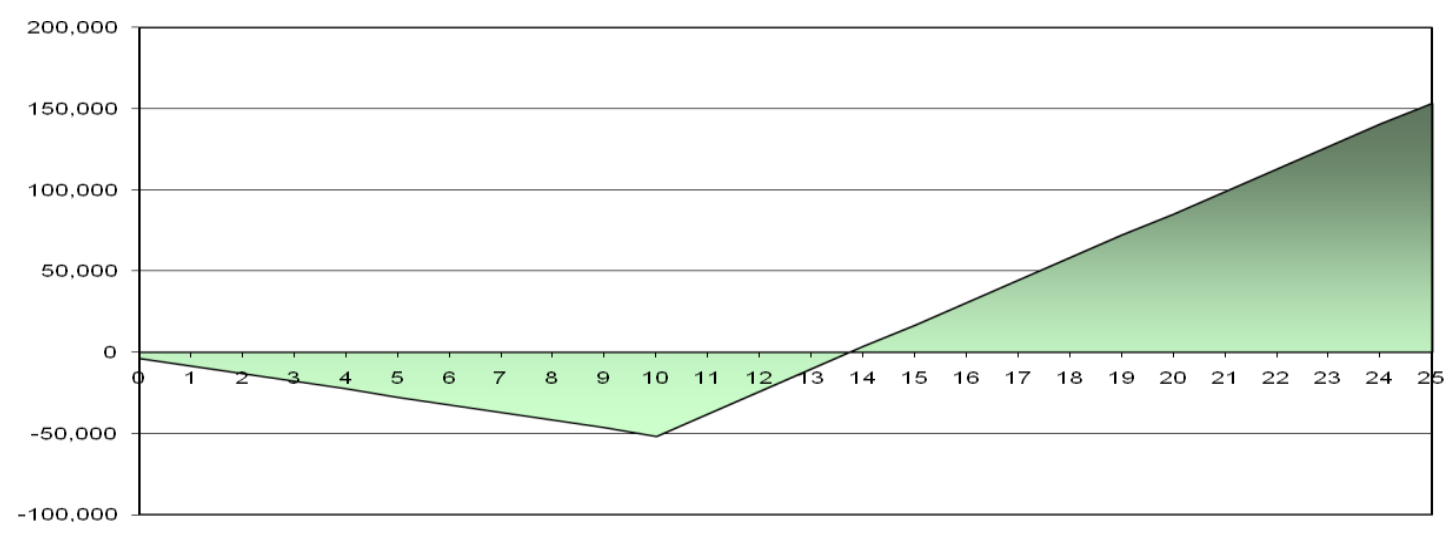

\section{Conclusion}

In this document the effort has been composed to estimate the financial and sensitive risk in the case of using the photovoltaic solar panel in the roof-top of the library of University of East London. In conclusion, based on this literature about diverse renewable knowledge's and particularly solar, a completely full life cycle evaluation of solar PVs would be useful to reduce the unclear application.

The major comparative concern emphasized throughout the PV array's analysis was its unexpectedly low down capacity factor. An analysis of other alternatives would be required to evaluate whether higher capacity factors could be reached with other technologies, like small wind turbines. The yield of other technologies is however suppose to also be restricted due to the university's critical urban location, with the adding of planning costs and time serving as yet more obstacles in more novel methods. It is show, the panel performs quite favorably over the full project term, displaying a gross annual go again of $2.5 \%$ on the sum primary capital invested, which is enhanced to $3.2 \%$ by the decline of the grant sum from the entirety initial cost. Given that the panel developed the university's picture in the borough and also in contrast to proposal at other institutions, and as well offers an academic chance for students in make known themselves through the technology in the course of actual knowledge, as well as other features like the development process which may be prepared for students, and also grant risk free go back on investment estimating traditionally like weather conditions in the future, the array is an brilliant social and academic chance and a admirable investment.

\section{Conflict of Interest}

"The authors declare no conflict of interest".

\section{References}

1. Biello, D. 2008, April 25. Retrieved April 8, 2010, from Scientific American: http://www.scientificamerican.com/article.cfm?id=solar-power-lightens-up-with-thin-film-cells 
2. Bilena, K. Ozyurta, O. Bakırcı, K. Karslıb, S. Erdoganc, S. Yılmaza M. \& Comaklı. O. Energy production, consumption, and environmental pollution for sustainable development: A case study in Turkey. Renewable and Sustainable Energy Reviews, 12 (6), 2008, pp. 1529-1561.

3. Boyle, A. $P G \& E$ makes deal for solar power. 2009. Retrieved April 8, 2010, from MSNBC: http://www.msnbc.msn.com/id/30198977/

4. Boyle. Oxford University Press. Renewable energy: power for a sustainable future, 1998. pp. 2060.

5. CALIFORNIA energy commission, G. D. Buying a PHOTOVOLTAIC solar system. Renewable energy program 2003.

6. Cambridge Econometrics. 2005. HM Revenue \& Customs. Retrieved April 10, 2009, from HM Revenue $\&$ Customs: http://customs.hmrc.gov.uk/channelsPortalWebApp/channelsPortalWebApp.portal?_nfpb=true\&_ pageLabel=pageVAT_ShowContent\&propertyType=document\&columns=1\&id=HMCE_PROD1 _023971\#P637_187238

7. Center, Florida Solar Energy. Installing Photovoltaic Systems. 1999

8. Department for Energy and Climate Change. 2009. Consultation on Renewable Electricity Financial Obligations. Retrieved December 5, 2009, from Department for Energy and Climate Change: http://www.decc.gov.uk/en/content/cms/consultations/elec_financial/elec_financial.aspx

9. Department of Energy \& Climate Change. 2009. Energy Statistics: Prices. Retrieved December 2, 2009, from Department of Energy \& Climate Change: http://www.decc.gov.uk/en/content/cms/statistics/source/prices/prices.aspx

10. Department of Energy \& Climate Change. 2009. LCBP Phase 2. Retrieved December 5, 2009, from Low Carbon Buildings Program Phase 2: http://www.lowcarbonbuildingsphase2.org.uk/

11. Gray-Davis, G. A Guide to PV system Design and Installations. 2001. California.

12. HM Treasury. 2009. Green Book Complete. Retrieved December 5, 2009, from HM Treasury: http://www.hm-treasury.gov.uk/d/green_book_complete.pdf

13. Hosseinian-Far, A. Jahankhani, H. Pimenidis, E. \& Wijeyesekera, D.C. Modeling of Sustainable Projects: A Solar Energy Review. Energy in the City Conference, South-Bank University, London. 2010

14. IEA. 1993. World Energy Model, Methodology and Assumptions. Retrieved from http://www.worldenergyoutlook.org: http://www.worldenergyoutlook.org/docs/annex_c.pdf

15. Omer, A. M. Energy use and environmental impacts: A general review. Journal of Renewables and Sustainable Energy 1, 2009. pp.101-2.

16. Mustafa, O. a. Energy use and environmental impacts: A general review. Journal of Renewables and Sustainable Energy.2009.

17. Mirasgedis, S.. Multicriteria analysis vs. externalities assessment for the comparative evaluation of electricity generation systems. European Journal of Operational Research 102 1997. pp.364379

18. Muneer, T. Sustainable production of solar electricity with particular reference to the Indian economy. Renewable and Sustainable Energy Reviews, 9 (5), 2005. pp. 444-473.

19. Retscreen. No Date. Retscreen user manual. Retrieved from retscreen international: http://www.retscreen.net/ang/d_t_guide.php 
20. Sherwani, A. Usmani, A. \& Varun, J. Life cycle assessment of solar PV based electricity generation systems. Renewable and Sustainable Energy Reviews, 2010, pp. 540-544.

21. The German Energy Society. Planning \& installing photovoltaic system. Earth scan in the UK and USA. 2010

22. Stringer, D. Hackers leak email, stoke climate debate. London 2009: The Associated Press.

23. Southern Electric. 2009.Solar PV Tariff. Retrieved April 9, 2010, from Southern Electric: http://www.southern-electric.co.uk/Help/ForYourHome/Microgeneration/SolarPVTariff.aspx

24. Toledo, A. Filho A. \& Cardoso, D. Distributed photovoltaic generation and energy storage systems. Renewable and Sustainable Energy Reviews, 2010, pp. 506-511.

25. Toklu, E. Guney, M. Isik, M. Comakli, O. \& Kaygusuz, K. Renewable and Sustainable Energy Reviews. 2010, pp. 1172-1186.

(C) 2011 by the authors; licensee MDPI, Basel, Switzerland. This article is an open access article distributed under the terms and conditions of the Creative Commons Attribution license (http://creativecommons.org/licenses/by/3.0/). 